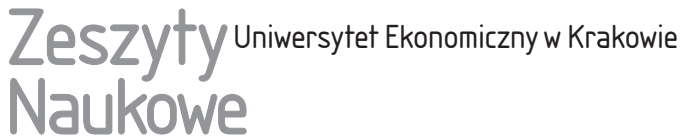

\section{The Technical Efficiency of Russian Retail Companies: An Empirical Analysis}

\begin{abstract}
This study focuses on the technical efficiency analysis of Russian retail companies over the period 2011-2015. The main objective is to assess technical efficiency and to reveal factors that affect the efficiency and creditworthiness of this important sector of the Russian economy. Efficiency can be considered a basic measure of creditworthiness because it demonstrates management's ability to maximise its use of resources. Studying the results enables banks to consider creditworthiness and determine whether to provide retailers with funding for future development. The empirical analysis for this article was performed using Data Envelopment Analysis and Stochastic Frontier Analysis methods. Two differing methods can be used to evaluate technical efficiency. The first, SFA, presents a picture of the whole market and formulates general propositions on the creditworthiness of retail companies. The other method, DEA, looks at certain companies and their relative performance in comparison with their competitors. Banks can use a technical efficiency score to monitor the dynamics and potential of each company. In addition to examining tools for evaluating technical efficiency, the study also has practical implications for managers of retail companies in Russia.
\end{abstract}

Elena Rogova, National Research University Higher School of Economics, Kantemirovskaya 3a, 194100, Saint Petersburg, Russia, e-mail: erogova@hse.ru

Alina Blinova, Raiffeisen Bank Russia, Troitskaya 17, bld. 1, 129090, Moscow, Russia, e-mail: ablinova@raiffeisen.ru 
Keywords: retail, technical efficiency, creditworthiness, Data Envelopment Analysis, Stochastic Frontier Analysis.

JEL Classification: L81, M11.

\section{Introduction}

One of Russia's most important economic sectors, retail is facing both global and local challenges. The growth of e-commerce, changing consumption models, and the decline of economic growth rates and household incomes all impact the market, pushing retail companies to seek methods of retaining customers and increase efficiency. In addition, retail companies usually depend to a great extent on external funding (due to the lack of internal sources and the specifics of credit policy), so it is important for them to be eligible to borrow and confirm their creditworthiness.

This paper focuses on the technical efficiency of retail companies. That is, it examines the inputs companies possess and the outputs they produce. It seeks to understand the technical efficiency of Russian retail companies and to find ways to improve it. The variables included in our models examine the technical efficiency of retail companies through the lense of their creditworthiness. Technical efficiency is considered a tool for negotiating with banks that assess the financial performance and take decisions on giving loans that retail companies can use to expand operations and maintain investment activities.

\section{Russian Retail Trade Sector - the Analysis}

With turnover of 28.3 trillion roubles annually, the Russian retail sector is among the country's most important. In 2016, it contributed $16 \%$ of national value added. Figure 1 presents the dynamics of the gross turnover.

It should be noted that high inflation rates (12.9\% in 2015 and 5.4\% in 2016) and the decline of household real incomes (3.2\% in 2015 and 5.9\% in 2016) affect the dynamics and performance of the retail sector. Physical turnover is decreasing, and the structure of the turnover is shifting to food, alcohol and tobacco products, which made up about 48\% of the entire volume of operations in 2015-2016.

As in other countries, Russian retail is consolidating rapidly as the share of the largest retail chains grows: it was $22.9 \%$ in 2013, 24.3\% in 2014 and $25 \%$ of overall turnover in 2015 (Butov 2017). In 2015, four Russian retail chains were among the largest world players (Table 1). 


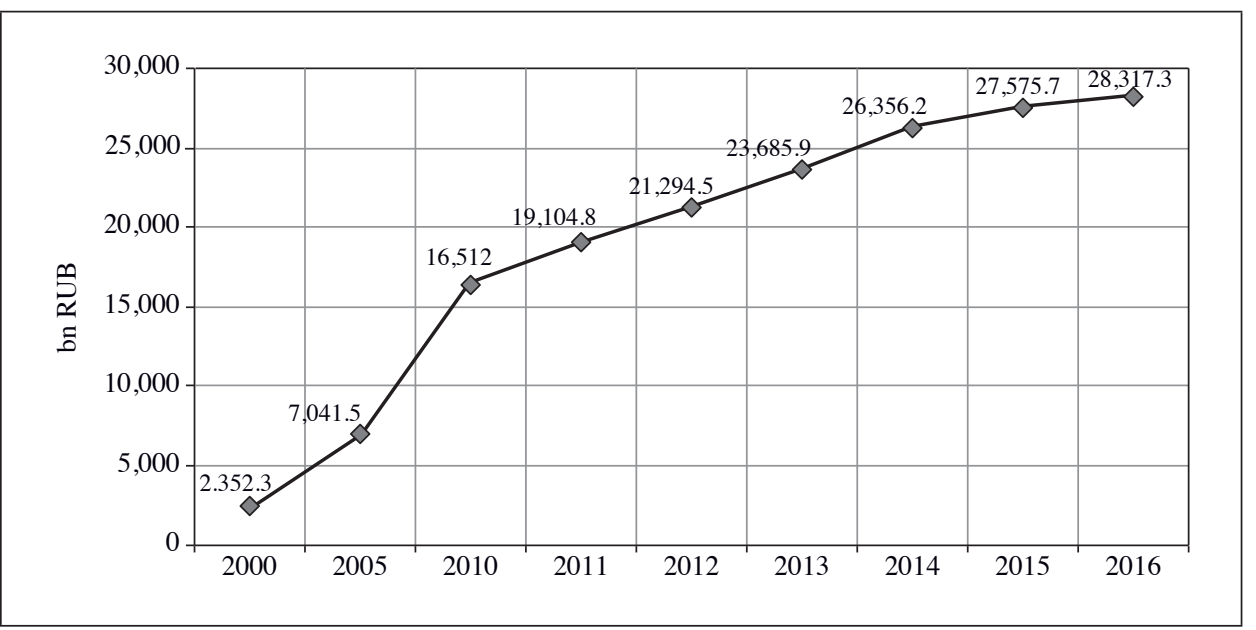

Fig. 1. Annual Turnover of Retail Trade in Russia, Billions of Roubles (Current Prices) Source: Russian Federation Federal State Statistics Service (2017).

Table 1. Russian Retailers among the World's Top 250 (2015)

\begin{tabular}{|c|c|c|c|c|}
\hline Rank & Company & $\begin{array}{c}\text { Sales } \\
\text { (USD Million) }\end{array}$ & $\begin{array}{c}\text { Net Income } \\
\text { (USD Million) }\end{array}$ & $\begin{array}{c}\text { Sales Growth } \\
\text { Rate }(\%)\end{array}$ \\
\hline 61 & Magnit & 15,677 & 977 & 32.0 \\
\hline 71 & X5 Retail Group & 13,378 & 234 & 18.7 \\
\hline 198 & Dixy Group & 4,473 & 10 & 33.5 \\
\hline 212 & Lenta Group & 4,181 & 170 & 29.0 \\
\hline
\end{tabular}

Source: Deloitte (2017).

The regional development of Russia's retail sector is unequal: $49 \%$ of total turnover comes from 11 regions while the remaining 69 regions together produce almost the same turnover.

With both the economic situation and the Russian government's trade policy (i.e. an embargo on food good imported from the EU and US) coming to bear on retail development, the new challenges the sector is facing globally have taken on a toll. For example, in the United States in 2016-2017, 36 retail chains announced bankruptcies, despite the fact that GDP and household income both grew. Retail chains are under growing competitive pressure from internet-based stores that actively use new technologies and increase their efficiency; they also face a changing model of consumption and people's increasing preference for experi- 
ence (travelling, entertainment) over shopping (Thompson 2017). These new trends underscore the importance of growing efficiency in this sector of the economy.

\section{Technical Efficiency as an Indicator of Management Quality}

The concept of efficiency is usually considered as the ratio of outputs (products or services) and the inputs used for their production. A producer is efficient if it reaches the maximum output with a given set of inputs or reaches a certain result with a minimal possible set of inputs (Greene 1997). The concept of technical efficiency, introduced by T. C. Koopmans (1951), is commonly used to assess organisations because it is helpful when multiple inputs and outputs are considered, and it is closely related to managerial efforts (Leibenstein 1966).

As retailers usually do not produce goods, their output can be measured by financial results. In this case, technical efficiency can indicate the quality of management. This study links technical efficiency with financial performance and creditworthiness, so it is necessary to explore the factors that influence the attractiveness of retail companies from the standpoint of external funding and its availability.

According to the theory of production, technical efficiency is the assessment of the resources' (inputs) vector that is used to obtain the vector of outputs. In making this assessment, companies transform inputs into outputs with a production technology.

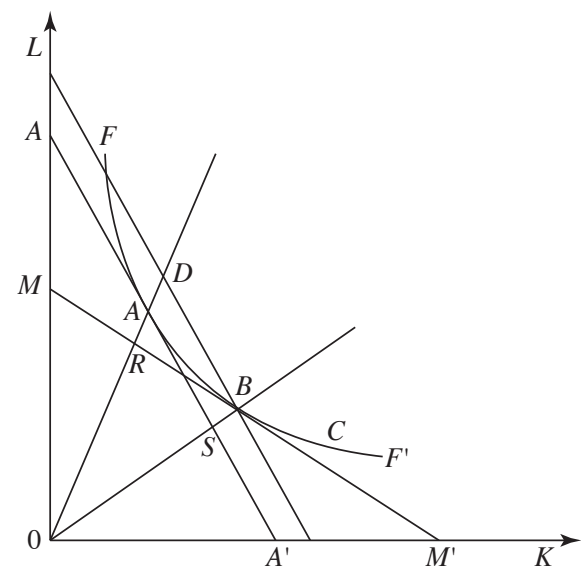

Fig. 2. Technical Efficiency under Two Inputs $(K, L)$

Source: the authors, based on Koopmans (1951). 
Let us assume that all trade companies have only two variables of inputs (labour and capital) with a constant return on scale and linear production function. The combination of inputs required for a certain output can then be presented as a point. The possible combinations of minimal possible inputs form an isoquant to the production frontier. The latter demonstrates the minimal possible sets of inputs required for a single output under the existing technology (in Fig. 2, points $A, B$, and $C$ lie at the isoquant $F F^{1}$ and are technically efficient combinations of inputs). Point $D$ is technically inefficient. Its efficiency is defined by the $O A / O D$ ratio, and while the technology of $A$ is available for $D$ (they lie at the same line), $D$ can increase efficiency by minimising inputs under the existing output.

Again, technical efficiency indicates a good deal about the quality of managerial decisions. If $M M^{1}$ reflects the production factor (input) prices available for all companies, and the optimal combination of inputs lies at line $O B$, then $B$ will be efficient, while $A$ and $C$ will be inefficient due to the wrong technology being chosen under existing prices. The basic criteria of efficiency can be described as follows:

$$
\min \frac{r K+w L}{Q}
$$

where:

$r$ - the cost of capital,

$K, w$ - the cost of labour $L$,

$Q$ - the output.

There are several methods of assessing technical efficiency, divisible into two groups - parametric and non-parametric. Methods from both groups were used in this study to test their practical applicability and increase the reliability of the results. They included Data Envelopment Analysis (DEA) and the Stochastic Frontier Approach (SFA).

Several earlier studies have evaluated technical efficiency in the analysis of retail companies. Using a non-parametric approach to assess retail stores in Australia, H. L. Kwok (2013) revealed the inefficient ones and elaborated recommendations for their reorganisation. C. P. Barros (2006) analysed hypermarkets and supermarkets in Portugal. The models they used were later compared with other models of retail organisation, with recommendations developed based on the benchmarking. A. Assaf, C. Barros and R. Sellers-Rubio (2011) analysed Spanish retail stores and revealed such factors of technical efficiency growth as vertical integration, low-cost strategy, age, and regional location. J. M. Xavier, V. M. Moutinho and A .C. Moreira (2015) examined branded apparel in Portugal and reported that for this market segment, because of the prevalence of "fast fashion", the most important factor was marketing and logistics, while age and learning experience did not matter. Similar results were obtained by W. Zhang 
and L. Guo (2010), who studied publicly traded retail companies in China. P. Jiang and S. Balasubramanian (2014) studied the efficiency of e-commerce and traditional retail forms, confirming that e-commerce is more efficient, particularly for multi-channel retailers and those who specialise in high-involvement products.

Using an approach based on the SFA, R. Sellers-Rubio and F. Mas-Ruiz (2006) revealed the determinants of efficiency in the Spanish retail sector - such as age, pricing, vertical integration, and geographical expansion - that coincide with the results obtained by A. Assaf, C. Barros and R. Sellers-Rubio (2011). Exploring Taiwanese retailers, R. Hwang et al. (2011) included financial indicators and reached two conclusions: first, that companies with low technical efficiency tended to be closer to bankruptcy, and, second, that the concept of technical efficiency in general may be used as an indicator for stability in financial performance.

In Russia, K.V. Bahtin (2009) explored the technical efficiency of production and retail companies using DEA and SFA together. He found a negative relationship between size and technical efficiency and between the volume of inventories and technical efficiency.

\section{Methodology}

In our study, we focus on creditworthiness and retail companies' potential to attract external funding (loans) for future development. Given the main purpose of our research and the results of previous studies, we chose indicators of inputs and outputs from the following list (Table 2).

Table 2. List of Variables for the Analysis

\begin{tabular}{|c|c|c|}
\hline Variable & Explanation & Name \\
\hline \multicolumn{3}{|c|}{ Inputs } \\
\hline $\begin{array}{l}\text { Financial leverage: } \\
\text { debt to equity ratio }\end{array}$ & $\begin{array}{l}\text { From the lender's standpoint, companies that can } \\
\text { partially refund debt from internal sources will be } \\
\text { preferred }\end{array}$ & FINLEV \\
\hline $\begin{array}{l}\text { Current liabilities to } \\
\text { net sales ratio }\end{array}$ & $\begin{array}{l}\text { Demonstrates the ability to generate cash flow that } \\
\text { covers the requirements of suppliers and other short- } \\
\text {-term lenders }\end{array}$ & CLNS \\
\hline $\begin{array}{l}\text { Fixed assets to equity } \\
\text { ratio }\end{array}$ & $\begin{array}{l}\text { From the lenders' standpoint, this figure should be } \\
\text { close to } 1\end{array}$ & FAOE \\
\hline $\begin{array}{l}\text { Current assets to sales } \\
\text { ratio }\end{array}$ & $\begin{array}{l}\text { Demonstrates the ability of a company to serve and } \\
\text { repay debts. The higher the ratio, the easier it is for } \\
\text { a company to repay its liabilities and the more reliable } \\
\text { it looks to a borrower }\end{array}$ & FICA \\
\hline
\end{tabular}


Table 1 cntd

\begin{tabular}{|l|l|l|}
\hline \multicolumn{1}{|c|}{ Variable } & \multicolumn{1}{|c|}{ Explanation } & Name \\
\hline $\begin{array}{l}\text { Equity to assets ratio } \\
\text { (autonomy ratio) }\end{array}$ & $\begin{array}{l}\text { Risk level based on the company's ability to finance its } \\
\text { assets by equity }\end{array}$ & AUTONOMY \\
\hline $\begin{array}{l}\text { Return on sales (net } \\
\text { income to sales ratio) }\end{array}$ & $\begin{array}{l}\text { Indicates the profitability of operating activities, pricing } \\
\text { policy, and cost structure }\end{array}$ & ROS \\
\hline $\begin{array}{l}\text { The ratio of internally } \\
\text { funded operating assets } \\
\text { to total operating assets }\end{array}$ & Indicates financial stability & OFR \\
\hline $\begin{array}{l}\text { Return on assets: net } \\
\text { profit from operations } \\
\text { to total assets ratio }\end{array}$ & $\begin{array}{l}\text { The main criterion of financial performance and the } \\
\text { quality of management's decisions }\end{array}$ & NPTA \\
\hline
\end{tabular}

Source: the authors' own work, based on standard Financial Analysis computations.

For this study, we tested the following hypotheses:

H1: Russian retail companies' technical efficiency for the 2011-2015 period was low.

H2: Creditworthiness is affected significantly by the scale of the business (market leaders are more efficient than smaller companies and niche actors).

H3: Technical efficiency differs by segments of the economy's retail sector.

H4: The age of a company significantly boosts its technical efficiency.

\section{Sampling}

The sample drew on data from the RUSLANA (Bureau van Dijik) database and included 504 retail companies. The following criteria were used:

- country of operational activity: Russia,

- legal status: legal entity,

- type of economic activity: retail trade in specialised and non-specialised stores,

- revenue: 500 million roubles and above,

- period: 2011-2015, indicators: yearly, type of data: panel.

In addition, we controlled the date of registration (proxy for the age of the companies) and used additional codes of economic activity (in order to segment the general sample). Within the sample, companies with negative meanings of indicators were excluded (DEA considers only non-negative meanings of inputs). We also controlled for omitted data. The final sample contained 111 companies and 555 observations. The sample was divided into six segments (Fig. 3). 


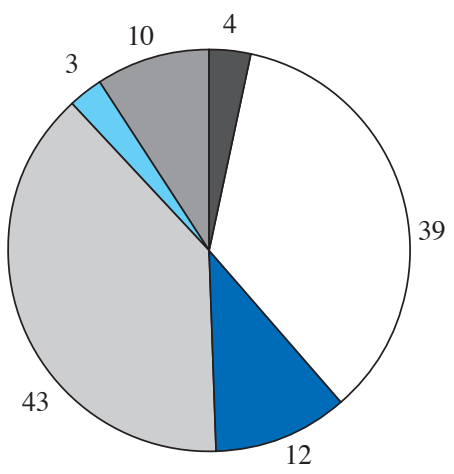

$\square$ Food $\square$ Fashion $\square$ Specialised $\square$ Drugstore $\square$ DIY $\square$ Electronics

Fig. 3. Sample Distribution by Retail Type

Source: the authors, initial data derived from RUSLANA database (https://www.bvdinfo.com/ru-ru/ our-products/company-information/national-products/ruslana, accessed: 10.05.2008).

Companies were also divided by their revenues (hereinafter, TR) at four quartiles (in billions of roubles):

1) market leaders, $\mathrm{TR}=[45.9086 ; 97.373]-2$ companies,

2) key actors, TR $=[5.556 ; 45.9085)-18$ companies,

3) participating actors, $\mathrm{TR}=[2.52275 ; 5.556)-15$ companies,

4) niche actors, $\mathrm{TR}=[0.5 ; 2.52275)-76$ companies.

\section{Results of the Technical Efficiency Analysis with Data Envelopment Analysis}

We used four inputs (CLNS, FAOE, FINLEV, FICA) and three outputs (AUTONOMY, ROS, OFR) in the model. The results were obtained using the DEA Frontier Solver package, implemented in Microsoft Office Excel.

As shown in Fig. 4, the share of technically efficient trade companies annually was $60-62 \%$, and the share of companies with a critically low level of efficiency did not exceed $3 \%$. Thirty-seven companies in the sample remained absolutely efficient for the whole period of observation, and among them there were retailers from all segments.

The model assessed the contribution of each of the variables to the total efficiency score (Fig. 5). The major slacks were revealed to be the financial leverage, autonomy ratio, and return on sales. 


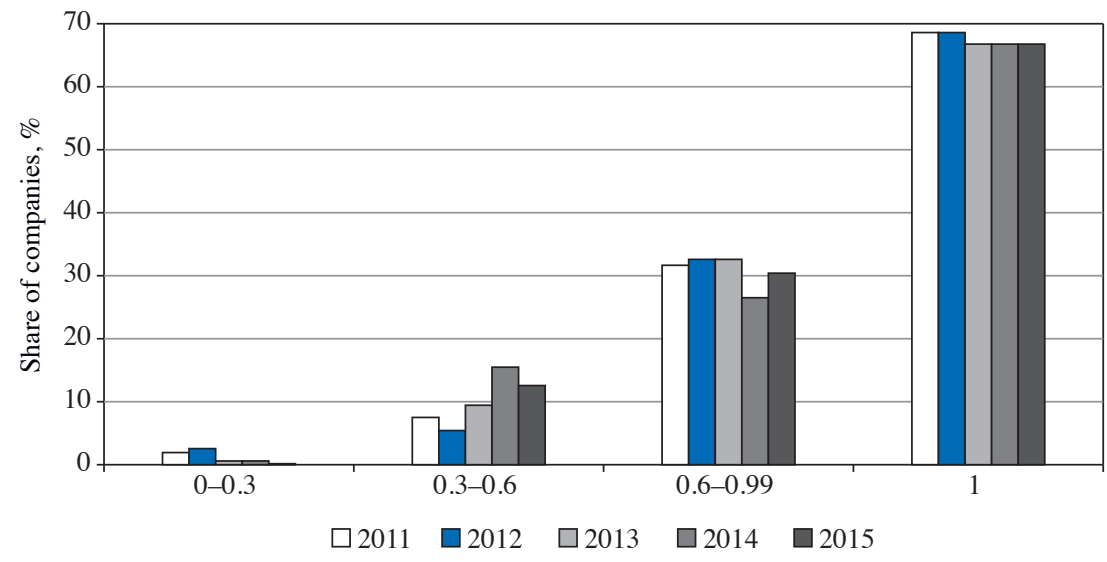

Fig. 4. Distribution of Companies by Efficiency Score (Horizontal Axis) Source: the authors, based on the results of modelling.

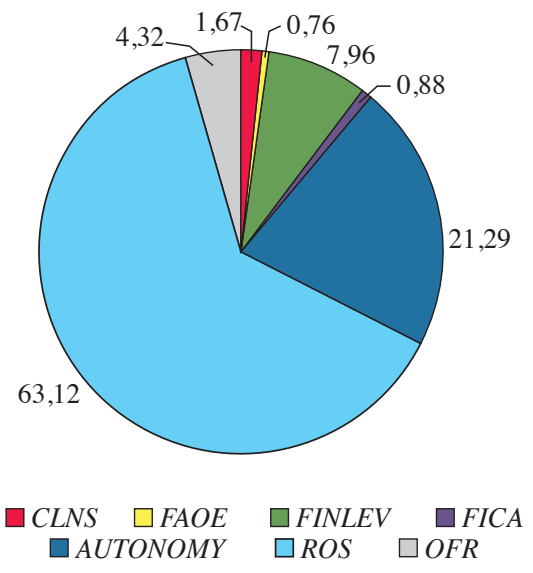

Fig. 5. Slack Analysis for Inputs and Outputs (in \% for Potential Improvements) Source: the authors, based on the results of modelling.

A positive relationship was revealed to exist between the age of retail companies and their technical efficiency score (Fig. 6).

Although there were efficient companies in all segments of the market, results revealed a relationship between the type of the retail activity and the efficiency 
score (Fig. 7). Fashion and electronics retailers demonstrated the lowest efficiency scores because they are so reliant on household income and are affected by currency swings (the goods are mostly imported).

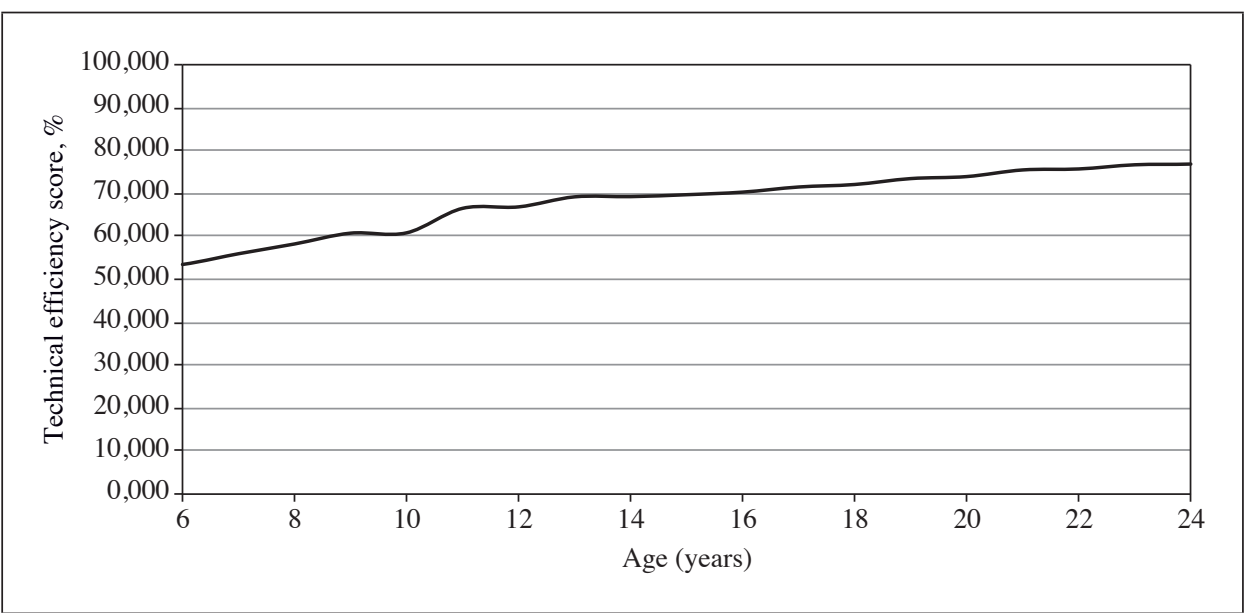

Fig. 6. Average Technical Efficiency Score (Multiplied by 100) Distribution by Retail Companies' Age

Source: the authors, based on the results of modelling.

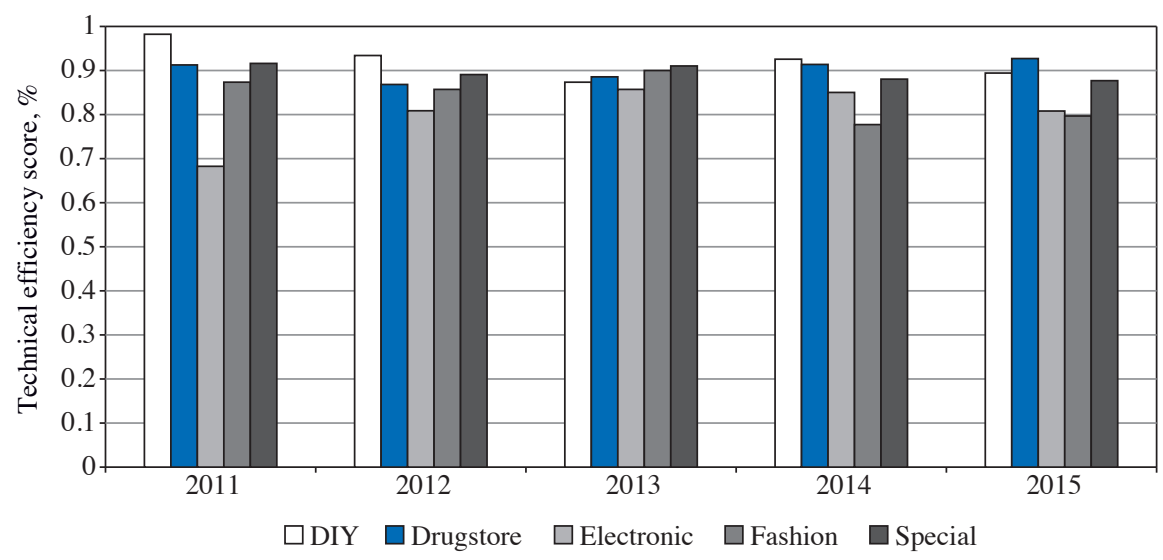

Fig. 7. The Distribution of Efficiency Scores by the Type of Retail Activity

Source: the authors, based on the results of modelling. 
We also ran a regression analysis to evaluate the variables by statistical means and set them in a range. The model obtained, however, had low explanatory power (the determination coefficient was only 23\%) and autocorrelation. This can be explained by the non-parametric nature of the DEA itself.

\section{Results of the Technical Efficiency Analysis Done with the Stochastic Frontier Approach}

For the SFA, we used the FRONTIER software package (Version 4.1c). The production frontier defines the form by the translog equation with the assumption of a normal distribution of residuals narrowed to zero:

$$
\begin{gathered}
\ln (\text { NPTA })=\ln (\text { FINLEV })+\ln (C L N S)+\ln (\text { FAOE })+\ln (\text { FICA })+\ln ^{2}(\text { FINLEV })+ \\
+\ln ^{2}(C L N S)+\ln ^{2}(F A O E)+\ln ^{2}(F I C A)+\ln (\text { FINLEV }) \cdot \ln (C L N S)+ \\
\ln (F I N L E V) \cdot \ln (F A O E)+\ln (F I N L E V) \cdot \ln (\text { FICA })+\ln (C L N S) \cdot \ln (F A O E)+ \\
\ln (C L N S) \cdot \ln (\text { FICA })+\ln (\text { FAOE }) \cdot \ln (F I C A)+\left(V_{i}-U_{i}\right),
\end{gathered}
$$

where NPTA, FINLEV, CLNS, FAOE, FICA were defined above, and $U_{i}$, and $V_{i}$ are residuals with the normal distribution narrowed to zero:

$$
u_{i} \sim \operatorname{iid} N^{+}\left(0, \sigma_{u}^{2}\right), v_{i} \sim i i d N\left(0, \sigma_{v}^{2}\right),
$$

( $v_{i}$ and $u_{i}$ are distributed independently from each other and from the variables).

The function is based on maximum likelihood estimation (for the sample of size I) I:

$$
\ln L=K-I \cdot \ln \sigma+\sum_{i} \ln \Phi\left(\frac{\varepsilon_{i} \lambda}{\sigma}\right)-\frac{1}{2 \sigma^{2}} \sum_{i} \varepsilon_{i}^{2},
$$

where $\varepsilon_{i}=u_{i}+v_{i}, \sigma^{2}=\sigma_{u}^{2}+\sigma_{v}^{2}, \Phi($.$) is a standard normal cumulative distribution.$ The function has a logarithmic nature, and $\varepsilon_{i}$ is replaced by $\ln E_{i}-\ln c\left(y_{i} ; w_{i} ; \beta\right)$.

The SFA model did not reveal the set of absolutely effective companies for the period of observation. Table 3 presents the OLS-estimation of the model.

Table 3. OLS Estimation of the Model

\begin{tabular}{|l|c|c|c|}
\hline \multicolumn{1}{|c|}{ Variable } & Coefficient & Standard Error & $t$-value \\
\hline$\beta 0$ & 2.4 & 0.15 & 15.96 \\
\hline$\beta 1($ FINLEV $)$ & 0.22 & 0.07 & 3.08 \\
\hline$\beta 2($ CLNS $)$ & -0.16 & 0.03 & -5.82 \\
\hline$\beta 3($ FAOE $)$ & -0.18 & 0.06 & -3.11 \\
\hline$\beta 4($ FICA $)$ & -0.35 & 0.06 & -6.38 \\
\hline
\end{tabular}

$\sigma^{2}=0.72610156 \mathrm{E}+00, \log$ likelihood function $=-0.69618140 \mathrm{E}+03$.

Source: the authors' own calculations. 
All coefficients are significant, as $t$ observed exceeds the critical value $\left(t_{(0.05 ; 111-4-1)}=1.983\right)$. Table 4 presents the final OLS estimation.

Table 4. Final OLS Estimation

\begin{tabular}{|l|c|c|c|}
\hline \multicolumn{1}{|c|}{ Variable } & Coefficient & Standard Error & $t$-value \\
\hline$\beta 0$ & 2.92 & 0.19 & 15.44 \\
\hline$\beta 1($ FINLEV $)$ & 0.02 & 0.09 & 0.20 \\
\hline$\beta 2($ CLNS $)$ & -0.12 & 0.03 & -3.42 \\
\hline$\beta 3($ FAOE $)$ & -0.09 & 0.08 & -1.10 \\
\hline$\beta 4($ FICA $)$ & -0.47 & 0.06 & -7.30 \\
\hline$\sigma^{2}$ & 1.99 & 0.30 & 6.68 \\
\hline$\Gamma$ & 0.86 & 0.02 & 35.22 \\
\hline
\end{tabular}

$\mu \neq 0, \varepsilon \neq 0$.

Source: the authors' own calculations.

To run the regression analysis aimed at the variables' range, we selected 100 companies randomly. Table 5 describes the variables included in the model.

Table 5. Description of the Variables Used to Estimate the Model

\begin{tabular}{|l|l|}
\hline \multicolumn{1}{|c|}{ Variable } & \\
\hline DEASCORE & Average technical efficiency score obtained with DEA (from 0 to 1) \\
\hline EFFSCORE & Efficiency score obtained with SFA (from 0 to 1) \\
\hline AGE & Age of companies (years) \\
\hline NPTA & Average meaning of return on assets for the period 2011-2015 \\
\hline CLNS & Current liabilities to sales ratio - average meaning for the period 2011-2015 \\
\hline FAOE & Fixed assets to equity ratio - average meaning for the period 2011-2015 \\
\hline FINLEV & Financial leverage - average meaning for the period 2011-2015 \\
\hline FICA & Current assets to sales ratio - average meaning for the period 2011-2015 \\
\hline Leader & Proxy for the market share (leader TR $=[45.9086 ; 97.373]$ ) \\
\hline Key & Proxy for the market share (key TR $=[5.557 ; 45.9085)$ ) \\
\hline Participant & Proxy for the market share (participant TR $=[2.52276 ; 5.556)$ ) \\
\hline Niche & Proxy for the market share (niche TR $=[0.5 ; 2.52275)$ ) \\
\hline Food & Proxy for the market segment \\
\hline Fashion & Proxy for the market segment \\
\hline Special & Proxy for the market segment \\
\hline Drug & Proxy for the market segment \\
\hline DIY & Proxy for the market segment \\
\hline
\end{tabular}

Leader TR: Total revenues for 2015, billions of roubles.

Source: the authors, based on the results of modelling. 
The final regression function looks as follows:

$$
\begin{aligned}
& \quad E F F S C O R E=1.1308+0.409 \cdot \ln (F I C A)+0.949 \cdot \ln (\text { NPTA })+ \\
& \quad+0.108 \cdot \ln (F A O E)+(0.0457 \cdot \text { Segment }+0.014 \cdot \text { Share }) .
\end{aligned}
$$

\section{Discussion and Conclusions}

Two methods demonstrate the different ways of evaluating technical efficiency. The DEA-based approach is characterised by higher efficiency scores than the SFA-based one, and the components of technical efficiency hardly correlate to each other. This can be attributed to the fact that the DEA is a non-parametric method and does not define functional dependencies between variables. Also, the two models rely on different assumptions. Still, we have arrived at findings that support or reject our hypotheses.

First, Russian retail companies' technical efficiency for the 2011-2015 period was indeed low. According to the DEA model, $60-62 \%$ of companies were efficient each year, but only $33 \%$ demonstrated absolute efficiency during the entire period. As for the SFA, none of the companies in the sample proved to be absolutely technically efficient.

Neither approach supported our second hypothesis, which was that creditworthiness is affected significantly by the scale of the business (market leaders are more efficient than smaller companies and niche actors).

The third hypothesis - that technical efficiency differs by segments of the economy's retail sector - was confirmed but only with the DEA analysis. Due to economic turbulence, electronics and fashion retailers demonstrate that lowest efficiency. For the SFA model, the sector differentiation did not demonstrate a strong relationship with the level of efficiency.

The fourth hypothesis - the age of a company significantly boosts its technical efficiency - was not confirmed. The companies' experience in the trade market positively affects creditworthiness, but according to the regression analysis, the variable characterising the companies' age proved insignificant.

Estimating technical efficiency based on the SFA allows us to present a picture for the entire market and formulate general propositions on the creditworthiness of retail companies. For lenders, this approach can be useful in understanding both the risks and opportunities a sector may present. The DEA encapsulates the market through certain companies and their relative performance in comparison with their competitors. Banks can use a technical efficiency score to monitor the dynamics and potential of each company.

To reach and maintain steady positions in the trade market, retailers must strive to accomplish four goals: to improve their asset management, filling the volume 
of the company's funds to cover the risk and financial liabilities; to increase the pace of business in the presence of borrowed funds, and to reduce the share of immobilised funds in the equity structure.

The study contributes to the discussion of business efficiency by exploring the development of tools that can be used to measure it. In practical terms, managers of retail companies in Russia can benefit from the lessons it reveals.

\section{Bibliography}

Assaf A., Barros C., Sellers-Rubio R. (2011), Efficiency Determinants in Retail Stores: A Bayesian Framework, "Omega", vol. 39, no. 3, https://doi.org/10.1016/j.omega. 2010.07.005.

Bahtin K. V. (2009), Ocenka i sravnenie tehnicheskoj effektivnosti rossijskihnpromyshlennyh $i$ torgovyh kompanij (Measuring and the comparing the technical efficiency of Russian manufacturing and trade companies), Working Paper BSP/2008/102R, New Economic School, Moscow.

Barros C. P. (2006), Efficiency Measurement among Hypermarkets and Supermarkets and the Identification of the Efficiency Drivers, "International Journal of Retail \& Distribution Management", vol. 34, no. 2, https://doi.org/10.1108/09590550610649795.

Butov A. M. (2017), Rynok roznichnoj torgovli produktami pitanija. 2016 g., Centr razvitija NIU VShE, Moscow, https://dcenter.hse.ru/data/2017/01/09/1115460812.pdf (accessed: 10.05.2018).

Deloitte (2017), Global Power of Retailing: The Art and Science of Customers 2017, http:// www2.deloitte.com/global/en/pages/consumer-business/articles/global-powers-of-retailing.html (accessed: 11.05.2018).

Greene W. H. (1997), Frontier Production Functions (in:) M. H. Pesaran, P. Schmidt (eds), Handbook of Applied Econometrics, vol. II: Microeconometrics, Wiley-Blackwell, Hoboken.

Hwang R., Siao J., Chung H., Chu C. (2011), Assessing Bankruptcy Prediction Models via Information Content of Technical Inefficiency, "Journal of Productivity Analysis", vol. 36, no. 3, https://doi.org/10.1007/s11123-011-0210-x.

Jiang P., Balasubramanian S. (2014), An Empirical Comparison of Market Efficiency: Electronic Marketplaces vs. Traditional Retail Formats, "Electronic Commerce Research and Applications", vol. 13, no. 2, https://doi.org/10.1016/j.elerap.2013.11.003.

Koopmans T. C. (1951), Analysis of Production as an Efficient Combination of Activities, "Activity Analysis of Production and Allocation", vol. 13.

Kwok H. L. (2013), Measuring the Distribution Efficiency of a Retail Network through Data Envelopment Analysis, "International Journal of Production Economics", vol. 146, https://doi.org/10.1016/j.ijpe.2013.08.008.

Leibenstein H. (1966), Allocative Efficiency vs. $x$-efficiency, "The American Economic Review", vol. 56, no. 3.

Russian Federation Federal State Statistics Service (2017), Retail Trade, Services to Population, Tourism, http://www.gks.ru/wps/wcm/connect/rosstat_main/rosstat/ru/ statistics/enterprise/retail/\# (accessed: 21.06.2018). 
Sellers-Rubio R., Mas-Ruiz F. (2006), Economic Efficiency in Supermarkets: Evidence in Spain, "International Journal of Retail and Distribution Management", vol. 34, no. 2, https://doi.org/10.1108/09590550610649803.

Thompson D. (2017), Causing the Retail Meltdown of 2017? "The Atlantic Daily", 10 April, https://www.theatlantic.com/business/archive/2017/04/retail-meltdown-of-2017/522384/ (accessed: 6.11.2017).

Xavier J. M., Moutinho V. M., Moreira A. C. (2015), Efficiency and Convergence Analysis in a Women's Clothing Retail Store Chain: Evidence from Portugal, "International Journal of Retail \& Distribution Management", vol. 43(9), https://doi.org/10.1108/ ijrdm-06-2014-0077.

Zhang W., Guo L. (2010), Analysis of Productivity and Efficiency Based on China's Retail Listed Companies, 2010 3rd International Conference on Information Management, Innovation Management and Industrial Engineering, Kunming, China, https://doi.org/ 10.1109/iciii.2010.42.

\section{Efektywność techniczna rosyjskich przedsiębiorstw handlu detalicznego. Analiza empiryczna}

(Streszczenie)

Tematem artykułu jest analiza efektywności technicznej rosyjskich przedsiębiorstw handlu detalicznego w latach 2011-2015. Główny cel stanowi ocena efektywności technicznej rosyjskich przedsiębiorstw handlu detalicznego oraz określenie jej determinant i wpływu na zdolność kredytową. Zdaniem autorów artykułu efektywność techniczną można uznać za główną miarę wiarygodności kredytowej przedsiębiorstwa. Określa ona zdolność kierownictwa do maksymalizacji wykorzystania zasobów. Na tej podstawie banki mogą oceniać zdolność kredytową przedsiębiorstw i podejmować decyzje o finansowaniu ich rozwoju. Do oceny efektywności technicznej analizowanych przedsiębiorstw wykorzystano metody SFA (stochastic frontier analysis) oraz DEA (data envelopment analysis). Metoda SFA pozwoliła na ocenę całego rynku i sformułowanie ogólnych wniosków na temat zdolności kredytowej rosyjskich przedsiębiorstw handlu detalicznego. Metodę DEA wykorzystano w analizie wybranej grupy przedsiębiorstw i ich względnej efektywności. Wskazano możliwości zastosowania omawianych metod w przeprowadzanej przez banki ocenie wiarygodności kredytowej przedsiębiorstw. Przedstawione wyniki oceny efektywności technicznej są również użyteczne dla menedżerów przedsiębiorstw handlowych w Rosji.

Słowa kluczowe: przedsiębiorstwa handlu detalicznego, efektywność techniczna, zdolność kredytowa przedsiębiorstwa, SFA (stochastic frontier analysis), DEA (data envelopment analysis). 